\title{
Wind erosion researches in Hungary - past, present and future possibilities
}

\author{
GÁbOr NÉGYESI ${ }^{1}$, JóZSEF LÓKI ${ }^{1}$, BотOND BURÓ², \\ BogLÁrKa BERTALAN-B ALÁZS ${ }^{1}$ and LÁsZLó PÁSZTOR ${ }^{3}$
}

\begin{abstract}
Wind erosion is one of the most important land degradation processes in Hungary in the areas with low yearly precipitation values. The total land area suffering from wind erosion is approximately $10,000 \mathrm{~km}^{2}, 10$ per cent of the country area. Observations and discussions on wind erosion and its negative impacts in Hungary started in the last century. Since the 1950s, scientists investigated wind erosion processes and their role in the evolution of alluvial fans in an integrative way, including laboratory measurements and field observations with respect to the stabilization and utilization of soils in agricultural areas. Since the late 2000s, there is an increasing demand worldwide to characterize the role of climate change and human activities in triggering land degradation processes. Studies have been conducted to investigate the mechanics, causes and control techniques related to wind erosion applying laboratory and field wind tunnel simulation tests and field observations. Some encouraging achievements have been made. In this paper we summarize the main research results of wind erosion research, and put forward some perspectives and suggestions on the problems of wind erosion research and control practices in Hungary.
\end{abstract}

Keywords: land degradation processes, soil erosion, wind erosion, wind erosion mapping

\section{Introduction}

Wind erosion, also known as eolian erosion is usually a natural, geological process that forms many aeolian landforms (LANCASTER, N. 1995), but today it is accelerated by anthropogenic effects (overgrazing, mismanagement of agricultural land, intensive crop cultivation etc.). Wind erodibility is determined by several static and dynamic factors, such as surface roughness, topographical surface characteristics, vegetation cover, pedological properties (particle size, soil structure, aggregate stability, soil moisture, lime and organic matter contents etc, see CHEPIL, W.S. 1954; SHAO, Y. 2008).

Wind erosion only occurs, when a threshold value of the wind velocity is reached, and this threshold value depends on soil surface properties. Threshold velocity $\left(u_{t}\right)$ or threshold shear velocity $\left(\mathrm{u}_{*_{\mathrm{t}}}\right)$ is the minimum friction velocity required to initiate the movement of soil particles, representing the strength of forces among soil particles and the capacity of an aeolian surface to resist wind erosion (BAtT, R.G. and Peabody, S.A. 1999; Shao, Y. and Lu, H. 2000). The conducted experiments also reveal the difference between static (or fluid) threshold and dynamic (impact) threshold. Static threshold indicates the moment when grains start to move. Once transport has started, it is bombardment that keeps the system moving and, because the descending grains bring down energy from above, less overall energy is required to maintain movement

\footnotetext{
${ }^{1}$ Department of Physical Geography and Geoinformatics, Faculty of Sciences, University of Debrecen. H-4010 Debrecen, Egyetem tér 1. Correspondent author's e-mail: negyesi.gabor@science.unideb.hu

${ }^{2}$ Institute for Nuclear Research, Hungarian Academy of Sciences, H-4026 Debrecen, Bem tér 18/C.

E-mail: bbotond86@gmail.com

${ }^{3}$ Institute for Soil Sciences and Agricultural Chemistry, Centre for Agricultural Research, Hungarian Academy of Sciences. H-1022 Budapest, Herman O. u. 15. E-mail: pasztor@rissac.hu
} 
and it can continue at a lower overall wind velocity than before. Consequently, the dynamic threshold, at wich grain movements can just be maintained, is about 80 per cent of the static threshold (ANDERson, R.S. and HAFF, P.K. 1988). As predictors of the field behaviour of soils, the threshold velocity should be treated carefully. Surface crust, rough surfaces, slope gradient, particles of different shape and packing density complicate the situation. The role of soil moisture and vegetation cover is also very important (Livingstone, I. and Warren, A. 1996).

Regarding soil structure, both size distribution and the actual condition of the soil aggregates are significant factors because they determine the resistance to wind erosion (Chepil, W.S. 1942; Lopez, M.V. et al. 2000; Hevia, G.G. et al. 2007). The $\mathrm{CaCO}_{3}$ content of the soil also plays important role in clumping of particles and in the formation of aggregates, as well as in the formation of a surface crust layer, which in turn protects against wind erosion (RAJOT, J.L. et al. 2003; Goossens, D. 2004; ZHANG, Y.M. et al. 2006). Organic matter has a similar role in erodibility to that of $\mathrm{CaCO}_{3}$. High levels of organic matter also facilitate the formation of small soil aggregates, and therefore the extension of wind erosion. In dry conditions the small mass per volume of organic matter may also lead to an increase of wind erosion (CHEPIL, W.S. 1954; Hevia, G.G. et al. 2003; De Rouw, A. and Rajot, J.L. 2004). Dry mechanical and dry clod stability decreases, the dry erodible material content increases as organic matter content decreases in the case of organic soils (Zовеск, T.M. et al. 2013). On the other hand, the organic matter content also increases the moisture retaining capacity of soils, and it also plays an obvious role in plant growth and development therefore - under a wet and rainy climate - it might indirectly increase the soil resistance towards wind erosion (TATARKo, J. 2011).

Soil moisture influences wind velocity required for soil movement initiation. A wet soil surface reduces wind erosion (SALEH, W. and FrYrear, D.W. 1995). The level of erodibility changes in accordance with the cohesive forces between the water molecules surrounding the soil particles. CHePIL, W.S. (1956) demonstrated that the degree of soil erodibility is in direct correlation with the soil moisture content. Bisal, F. and Hsien, J. (1966) came to a similar conclusion. According to them, 4 per cent water content $(\mathrm{g} / \mathrm{g})$ would be enough for sandy texture soils to prevent wind erosion. NickLING, W.G. (1978) studied dust storms and the environmental conditions responsible for wind erosion of sandy soils in Canada. He found that the critical soil moisture content is around 3-4 per cent. Troen, F.R. et al. (1980) demonstrated that in case of sand texture soils, when the climate conditions promote quick dehydration of the soil surface, wind erosion begins as early as 15-20 minutes after a heavy rain. Leuven, M.L. (1982) investigated the correlation between the water content and the time duration when the wet soil surface was capable to resist the wind forces at 50 $\mathrm{km} / \mathrm{h}$ wind velocity. He found a linear function between the two factors. CHEN, W. et al. (1996), based on wind tunnel experiments, established that with the increase of the water content the quantity of the eroded soil material decreased exponentially. YAN, Y. et al. (2015) pointed out that soil erodibility changes dramatically under small quantities of rainfall.

Another consequence of rainfall or irrigation is soil surface sealing or crusting on unconsolidated soils. Crusts have a pronounced effect on the susceptibility of soils to wind erosion because their properties differ from those of unconsolidated soils (Zовеск, T.M. 1991). Soil crusts reduce the susceptibility of the soil to erosion when exposed to wind (Chepil, W.S. 1956; Zobeck, T.M. 1991). Wind tunnel and field studies have demonstrated that crusted soils erode at a rate of one-fortieth (Zовеск, T.M. 1991) to one-sixth (CHePIL, W.S. 1958) the rate of non-crusted soils. This fact is particular important in arid and semiarid regions where the vegetative cover may not sufficiently protect soils from wind erosion. Zовеск, T.M. (1991) found that crusts formed on silt loam and clay soils can be much more effective in reducing the total soil 
erosion under various abrasion conditions than can those formed on a sandy loam soil. In addition, soil crusts increase the entrainment threshold, as has been suggested by the large amount of work that has been conducted on how crust disturbances increase dust emission (Belnap, J. and Gillette, D.A. 1997; Baddock, M.C. et al. 2011). Threshold friction velocity increased exponentially with an increase in crust strength and thickness for five soils commonly found across the Columbia Plateau (Sharratt, B.A. and Vaddella, V. 2014).

Vegetation cover also plays an important role in preventing wind erosion (ARMBRUst, D.W. and Bilbro, J.D. 1997). The presence of vegetation on the surface increases the turbulence close to the ground and therefore decreases wind velocity (SHAO, Y. 2008). Vegetation cover of about 20 per cent can reduce the soil loss by half compared with a bare surface, while soil cover greater than 10 per cent can effectively reduce wind erosion (Fryrear, D.W. et al. 1996). Vegetation can also increase soil moisture content through shading effect, but the influence of vegetation cover on soil moisture content has been a controversial issue, because the vegetation extracts water from soil through transpiration, and secondly it can alter the temperature of soil as well (WANG, T. et al. 2015). Bare soil and arable lands are most seriously affected by wind erosion. Because the vegetation cover changes in space and time, it is more straightforward to characterise an area only with the potential exposure, which can be characterised by susceptibility to wind erosion.

Tillage operations modify the surface crust, change random (clods) and oriented (ridges and furrows) roughness, flatten and bury crop residues. The roughness immediately after tillage depends upon the implement used, the operating characteristics (depth, speed, residue level, soil texture and moisture) and the previous operation (Nelson, R.G. et al. 1993).

Wind erosion is a serious problem all over the World, the total area of agricultural lands affected by wind erosion is 550 million ha. Areas most susceptible to wind erosion around the world are the agricultural areas in the USA and Canada in North America; in the drier parts of Argentina, Bolivia and Peru in South America; the Siberian Plain in Russia; in China, India and Pakistan and much of the Middle East in Asia; North and South of the equator in Africa; and in Australia (SKIDmore, E.L. 1986). In Hungary the proportion of agricultural land strongly endangered by wind erosion is 26.5 per cent of the total area, whilst the percentage of moderately endangered areas is over 40 per cent (LóKI, J. 2003).

Nowadays, the endangered areas of Hungary are mainly affected by human impacts and just a little by climate. It is important to emphasize that wind erodibility of our soils is not only a soil conservation problem, but it also presents economic (nutrient loss), environmental and human health problems.

Accelerated soil erosion by wind results in both on-site and off-site damages. In agricultural lands, wind erosion causes the removal and transportation of the finest and biologically most active parts of the soil, which are the richest in organic matter and nutrients (FunK, R. and Reuter, H.I. 2006). A substantial consequence is the decline in the productivity of endangered areas. Furthermore, the transport of nutrients and pre-sowing herbicides by wind erosion can also be considered as a serious environmental problem (FUNK, R. et al. 2004). In addition, wind erosion causes considerable crop damage, especially to young seedlings, and increased farm maintenance costs. Off-site damage includes adverse health impacts caused by dust storms over vast areas, and harm to transportation, communication and irrigation infrastructure (SHI, P. et al. 2004).

Wind erosion similarly to water erosion (Keller, B. et al. 2018; WALtNer, I. et al. 2018) is also a land degradation process. By reviewing recent research progress, our objective is to stimulate further advances in wind erosion research. As part of this review we also highlight research gaps and opportunities. We conclude by outlining our views on the future of wind erosion research in Hungary. 


\section{Progress of wind erosion research in Hungary}

Wind erosion resaserch in Hungary made an important progress related to the dynamic, influencing factors, measurement, estimation and control techniques of wind erosion. The first studies of wind erosion were performed in the field of aeolian geomorphology because the research topic at that time was the morphology and evolution of sand dunes. Studies were carried out on the formation of different eolian forms and on the age of sand movements in that areas. It was recognized early, that the sandy areas are situated on alluvial fans built by different rivers (Figure 1).

Despite the fact that the phenomena and consequences of wind erosion were observable in Hungary year by year and discussions on the negative effects of wind erosion have already been known since the $18^{\text {th }}$ century, research activities on wind erosion started almost more than a century later. An explanation of this can be the underestimation of the importance of wind erosion in a certain extent. The harmful effects of wind were known, so the agronomists, on the basis of their empirical observations, were concerned about the protection of wind-susceptible areas and not so much in understanding the process itself. Measurements were not made, so the characterization of the erosive activity of wind was not possible. Equipments for measuring the amount of eroded material by wind were not available either (LóKI, J. 2008).

In the drier periods of the last century (1962, 1968, 1983, 1998), according to the Pálfai drought index (PÁlfaI, I. 2011), the damages caused by wind erosion have inreased, due to the improper farm management on large plots. The damage caused by wind erosion called for the the need of research on this topic. Bodolay, I. (1965b, $1966 b)$ was the first who dicussed the prob-

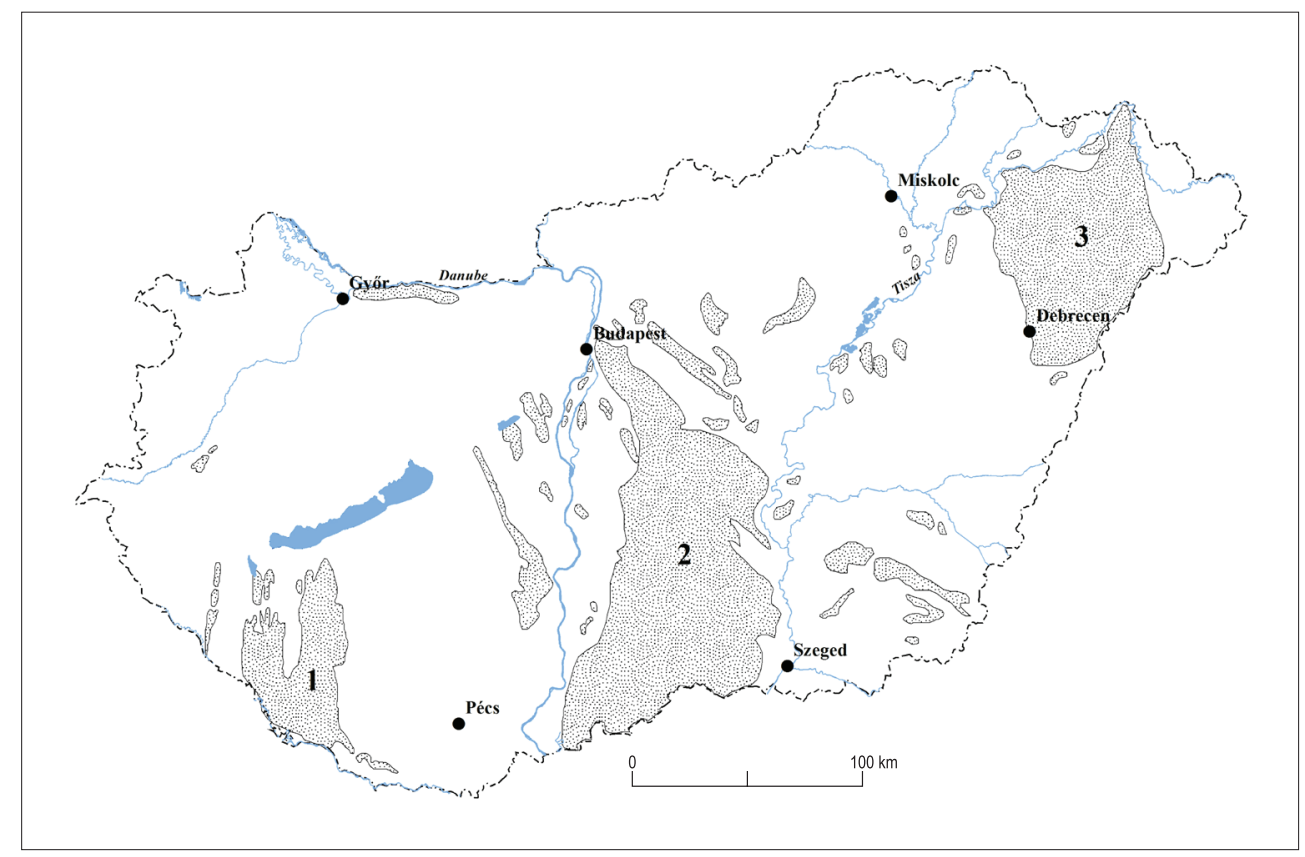

Fig 1. Sandy areas in Hungary and the main sandy regions (by Buró, B. et al. 2018). - 1 = Inner-Somogy; 2 = Danube-Tisza Interfluve; 3 = Nyírség 
lems and processs of wind erosion on the basis of international literature. She also studied and measured (Bodolay, I. 1966a) the amount of wind-driven material on differently cultivated (I: stubble, autumn ploughing, II: stubble, spring ploughing, III: disking, autumn ploughing, IV: disking, spring ploughing, $\mathrm{V}$ : rye) experimental plots applying small $(12,5 \times 10 \mathrm{~cm})$ plastic boxes inserted into soil. The used sand traps didn't facilitate the qualitative measurements of various forms of aeolian transport (rolling, saltation, suspension) yet, however, they pointed to the need of the application of well-designed sand traps. In the DanubeTisza Interfluve, measurements related to the amount of wind-driven material were also executed by Szeifrid, E. and KIs, L. (1969) by the application of Bodolay's sand trap.

Aerodinamically shaped sandtrap-boxes were used by Borsy, Z. (1974) which were placed at different heights above the surface and plastic bags were also inserted into the soil. These measurements provided useful data with repect to the mechanical composition and distribution of soil particles moving on and above the surface at different heights. Unfortunately, the applied traps were not suitable for the precise measurement of the total amount of wind-driven material, because of improper aerodynamic operation. First of all, the inlet of these traps was made of a $5 \mathrm{~mm}$ wide plastic material so some parts of the moving particles collided with this and didn't pass into the boxes, secondly the wind could blow out the particles from the boxes. After that, as a result of a co-operation with physicists, aerodinamical horizontal sandtraps were constructed, which were suitable for the identification of the amount, mechanical composition and distribution of wind-driven material. Borsy, Z. studied wind erosion processes in more detail by experiments in Nyírség and in the Danube-Tisza Interfluve under field conditions applying new horizontal and vertical Bagnold-type sandtraps (Borsy, Z. 1972). On the basis of his extensive field measurements, he concluded that if the wind velocity reached 5.5-6.0 m/s, the amount of sand flux was very high (Borsy, Z. 1974).

As the result of his research activities, the first wind tunnel of the country was built 30 years ago which is still the only wind tunnel applicable for wind erosion experiments (LókI, J. 2003). This wind tunnel was very useful in the analyses of the principals of wind erosion. Parallel with field measurements, experiments were also conducted in the wind tunnel. Initially, aeolian sand was used in wind tunnel experiments where the threshold velocity and wind profile as well as the amount and particle size distribution of eroded material were measured. The results were compared with the results of field experiments and also with international measurement data. Thanks to the huge amount of wind tunnel and field measurements the clarification of the principles of wind erosion on sand areas became possible (Borsy, Z. 1974).

Király, M. and Karácsony, J. (1977) also measured the transport capacity of wind and studied the weather factors causing wind erosion in the Danube-Tisza Interfluve. Karácsony, J. (1974) developed a new type of anemometer for the measurement of surface wind velocity which facilitated the measurement of velocity and wind turbulence.

Unfortunately, the harmful effects of wind erosion are present on heavy textured, silty soils, too and not only on sandy areas and dry, peaty surfaces. The negative consequence of the improper application of soil tillage methods is the failure of soil state which creates favourable conditions for wind erosion. Therefore the wind erodibility of other soil texture classes was also determined. On the basis of wind tunnel experiments the pricnciples of wind erosion for heavy-textured soils were identified and the fundamental parameters (critical threshold velocity, soil loss rate, wind profiles) were established and stored in a wind erosion information system (BLAskó, L. et al. 1995; LóKI, J. 1994, 2000, 2003; LóKI, J. et al. 2005).

In the last years, comparative analyses of wind tunnel measurements were also conducted to investigate the erodibility of differ- 
ent soil texture classes (number of samples: sand: 19 , loamy sand: 21 , sandy loam: 26 , loam: 8, silt loam: 6) and the relationships between soil properties and wind erosion. It could be proved that the rate of soil erosion, after having reached the threshold velocity, suddenly increased with a further increase in velocity. This was confirmed by the exponential relationship between wind velocity and the weight of the eroded soil mass. Soils with a sandy texture were an exception, since in these cases a linear correlation between the two factors was found. The particles of sandy soils started to move at a relatively low (6-7 $\mathrm{m} / \mathrm{s}$ ) velocity, while the movement of silty soils started at higher velocity values (10-11 $\mathrm{m} / \mathrm{s})$, and the process of erosion did not start suddenly, but gradually.

Regarding the erodibility of soils with different texture classes the conclusion is that the mass loss of sandy texture soils was ten times higher than in the case of a silt loam texture (NÉGYESI, G. et al. 2016). It was proved by statistical analysis that both the threshold wind velocity and erodibility depend primarily on the soil's mechanical structure and composition:

(1.) A strong negative correlation was observed in the sand fraction up to $0.10-0.05$ $\mathrm{mm}$, and, from that point on in the case of finer fractions the sign of the correlation changed and there was a strong positive relationship. Accordingly, the higher the amount of particles $0.10-0.63 \mathrm{~mm}$, the lower the threshold wind velocity; furthermore, the higher the amount of particles smaller than $0.1 \mathrm{~mm}$, the higher the wind velocity needed to move them. The role of soil fractions in the erodibility of soils was also examined. Although, each variable was found to be significant, the most important one was the coarse silt fraction $(0.05-0.02 \mathrm{~mm})$.

(2.) Organic matter had a significant correlation with the eroded mass $(r=-0.57$, $\mathrm{p}<0.01)$; however, it did not play any role in the regression due to its limited influence.

(3.) The same was experienced with other variables (other fractions and $\mathrm{CaCO}_{3}$ ), i.e. in spite of their correlation with erosion their contribution was not significant in the multivariate regression model. Maybe, it was due to the fact that the organic matter and $\mathrm{CaCO}_{3}$ content of these soil samples were relatively low (NÉGYesi, G. et al. 2016).

However, these results of wind tunnel measurements are of only a theoretical importance because the erodibility of soils is influenced by a number of other factors as well, both temporally and spatially. Furthermore, cultivation plays an especially important role, as the different planting cultures may influence the erosion rates in significantly different ways (Zовеск, T.M. et al. 2000). It is important to emphasize that when cultivated improperly, in the long run even soils with a finer texture are susceptible to significant transportation because as a result of tilling/ disking the soil structure may collect dust, and in the absence of the protecting function of larger aggregates, the silt fraction may easily be removed by the wind.

Today the emphasis is on new topics related to new equipments, perspectives and technologies. Since the forecasts of global warming indicate that the effects of Mediterranean climate will be stronger (increasing summer temperature values and a decreasing amount of summer precipitation), it probably will enhance the occurrence of wind erosion on both Arenosols and Chernozems in the Carpathian Basin (FARsANG, A. et al. 2017). Widespread experimental researches have been conducted in different parts of Hungary aiming at the objective measurement of the spatial and temporal changes of wind erosion processes under natural field conditions, and trying to determine the composition and nutrition content of the eroded material. These studies focus on the identification of threshold friction velocities on different aggregated soils and on quantifying soil loss in different wind erosion events with the help of a portable wind tunnel (FARSANG, A. et al. 2013a, b).

The conclusion is that the structure, carbonate and organic matter content of the studied Chernozem soils have a strong effect on the measured threshold friction velocities and total soil loss. So these factors cause big dif- 
ferences in wind erosion susceptibility and highlight the importance of suitable agrotechnology against wind erosion (FARSANG, A. et al. 2017). Wind tunnel experiments were also conducted to determine the nutrient content loss of soils eroded by wind with sand traps at different heights. On the basis of these measurements it can be established that the majority of the eroded material was trapped at a height of $0-10 \mathrm{~cm}$ and only $20-30$ per cent at a height of 10-40 cm (FARSANG, A. et al. 2011; TAtÁrvÁri, K. and NÉGYESI, G. 2013). The transported material collected in the traps had smaller nutrient content than the controll material because of its smaller silt and clay content. In the case of soils containing sand between 50-90 per cent the salt concentration of the sediment was higher than that of the control samples. Intensive $\mathrm{NO}_{3}-\mathrm{NO}_{2}-\mathrm{N}$ accumulation was observed in the wind-blown soil fractions. The $\mathrm{NO}_{3}-\mathrm{NO}_{2}-\mathrm{N}$ content of the sediment may be more than double of the original content of the soil. The enrichment of phosphorus, potassium and sodium contents was also observed in the sediment (TAtárvári, K. and Négyesi, G. 2013).

On sandy soils SzATMÁri, J. (2004), Buró, B. (2016) and Buró, B. et al. (2018) determined the thickness and volume of the eroded and accumulated sand on field sites with the help of measuring pin. SzatmárI, J. (2004) studied the amount of sand exposed to wind erosion on a $50 \times 50 \mathrm{~m}$ study site on a sand ridge in the Danube-Tisza Interfluve. Sand movement was measured at weekly and fortnightly intervals. The most intensive sand movement could be observed during springs, when the amount of monthly total transported sand exceeded 50 tons for the one-quarter hectare of the lot. The wind gusts were about $20-25 \mathrm{~m} / \mathrm{s}$ several times in the experimental period. SzATMÁrI, J. set up a portable digital measurement station for monitoring wind erosion on the field (saltiphone, it can transform the impulses from acoustic microphones that detect sand particle impact into digital ones). The sensors in this device can detect 1-3,000 particle impacts per second, thus it can measure the exact time when the saltating particles begin and finish to move. Measurements and statistical analyses proved that the well known cubic function can describe the correlation between the wind speed and the quantity of the number of the saltated particles. These experiments supported earlier results in scientific literature that the applicability of the device with acoustic microphone is limited to defining the quantity of the eroded material.

Buró, B. conducted his measurements in Nyírség (see Figure 1) on a 50 x 500 m study site on a hummocky dune. The study site contained two different plots: one of them was a bare surface without planted vegetation, the second one was a plot site planted with rye. He stated that the most intensive entrainment by wind ( 60 tons/ha) could be observed during early spring on the bare field. The greatest erosion at this time was $7-8 \mathrm{~cm}$ while maximum accumulation varies between $0.5-2.0$ $\mathrm{cm}$. That can be explained by more windy conditions in March and April $(10 \mathrm{~m} / \mathrm{s} \mathrm{sev-}$ eral times), less wet weather and the lack of land cover or underdeveloped vegetation. Intense entrainment was measured on the top of the hummocky dune and accumulation processes were active at the bottom of the slope of the hummocky dune. From the middle of May the quickly growing rye was able to reduce wind erosion (between -0.25 and $-0.80 \mathrm{~cm}$ ) and lead to an intensive accumulation reflected by the increase in the average surface change values. Measurements in June and July hardly showed any transport by wind from the study site, neither from the bare, nor from the vegetated surface (Buró, B. 2016; Buró, B. et al. 2018).

The wind-erodible fraction (EF) of soil aggregates $(<0.84 \mathrm{~mm}$ dry soil aggregates) is also an important parameter for estimating wind erosion. Measurements were also conducted on 150 soil samples from the Nyírség (the second large sandy area in Hungary, see Figure 1) to reveal the relationship between EF and the physical properties of soils. The examined soil samples belong to sand (22), loamy sand (32), sandy loam (68), loam (18) and silty loam texture (10). The results showed that all the examined soil properties 
(organic material-, $\mathrm{CaCO}_{3}$ content, sand, silt and clay content) were significantly correlated with EF. The strongest relationships were found between EF and textural fractions, being positive for the sand content and negative for the silt and clay contents. Although weaker than the relationship between EF and texture, a significant negative correlation was also observed between EF, soil organic matter and $\mathrm{CaCO}_{3}$ contents. The equation proposed by Fryrear, D.V. et al. (1996) for estimating EF was also tested and it was not suitable for predicting the EF of soils in the Nyírség region (NÉGYESI, G. 2018a, b).

\section{Research of wind erosion control methods in Hungary}

The inhabitants of the areas susceptible for wind erosion have long recognized the importance of wind erosion control. Many studies dealt with with the methods of fixing of sand. The territories covered by loose sand were surveyed and plans were prepared for reforestation. This process strengthened in the second part of the $19^{\text {th }}$ century. It is important to mention research activities of Westsik, V. (1922, 1951) and Egerszegi, S. $(1961,1962)$, who dedicated a lot of time to improve the productivity of sandy soils and to decrease harmful effects of wind erosion. They used the laminated sand cultivation method, i.e.the allotment of different materials (farmyard manure mixed with clay, with bug, or with lignite) into the soils at a depth of $80-90 \mathrm{~cm}$. This method resulted a $40-60$ per cent increase of crop production.

The protection effects of irrigation on sandy soils was examined by Bodolay, I. (1965a) in June, on six plots, 2,000 $\mathrm{m}^{2}$ each which with spray irrigation received the following amount of water: treatment 1 : nonirrigated, treatment 2: $10 \times 5 \mathrm{~mm}$ each third day, treatment 3: 1 x $50 \mathrm{~mm}$. In the course of treatment 4 windy periods occurred with a wind velocity of 7.0, 6.0, 5.0 and $5.7 \mathrm{~m} / \mathrm{s}$. The time period of the wind events was: 32 , 8,16 and 32 minutes each. The experiments revealed that the moisture content of the surface becoming frequent irrigations with $5 \mathrm{~mm}$ water effectively hindered wind erosion. Non-irrigated plots and those irrigated with $1 \times 50 \mathrm{~mm}$ were 10 to 20 times more erodible than the plot irrigated with $10 \times 5$ $\mathrm{mm}$. The safety of the effect of erosion was enhanced by the crust developed on the surface, which enhanced the resistance of the soil drying before irrigation. This mode of irrigation, however, is also advantageous for the emerging plants, since in this case the moisture is stored in the upper soil layer most available for the plants.

Bodolay, I. also studied (1966b) the effect of various soil cultivation methods on wind erosion on 20 plots (the size of one plot was $100 \mathrm{~m}^{2}$ ). The used soil cultivation methods were as follows: stubble, spring ploughing; rye; stubble, autumn ploughing; disking, autumn ploughing) Most conspicuous was the high erodibility of loose sandy soils after rolling. On 28 windy days on the rolled plots of smooth surface 11.5 times as high soil erosion was observed as on the (ploughed, disked) plots free of vegetation on 32 windy days (mean velocity $6.3 \mathrm{~m} / \mathrm{s}$ ). Resistence to wind erosion of the rough (plough, disked) soil surface was connected with the degree of roughness or cloudiness. Freshly ploughed soil surface afforded good protection. With her co-workers successfull field experiments were performed with different soil covering polimers and latex-emulsions (Bodolay, I. and Pusztai, A. 1968; Bodolay, I. et al. 1971) and they found that these materials offer good protection against wind erosion.

In the middle of the 1970's a country-wide collaboration evolved between soil scientist experts working on wind ersion control methods. GÁL, J. (1966, 1974) offered wind shelterbelts and forests as wind erosion control methods. He pointed out that in the case of peat soils on an occassion of a stronger wind erosion event such a large amount of dust (340-1,100 tons $/ \mathrm{km}^{2} /$ year) is emitted into the atmosphere which is harmful for the human respiratory system. His experimental data obviously proved that with the reduc- 
tion of the force of the wind the shelterbelts sieve out a significantly great part of the vitiation of the air and prohibit the formation of dust storms. On the area examined behind the shelterbelt at the point of minimum dust content a value of 340 tons $/ \mathrm{km}^{2} /$ year and at the furthest maximum point of the belt 1,102 tons $/ \mathrm{km}^{2} /$ year were measured. Comparison of the upper horizon of soil profiles examined at the points of maximum and minimum protection on the basis of the data of 57 soil profiles clearly indicated that at the protected points the organic matter content of the soil, percentual ratio of the clay and silt fractions were substantially higher than at the points in the middle of the field because of the wind velocity reducing effect of the shelterbelts.

Among geographers, research activities of Borsy, Z. (1974) should be mentioned. On the basis of the results of field experiments in Nyírség and and also in the wind tunnel he verified that trye stripes perpendicular to the prevailing winds can decrease the wind velocity significantly. According to his measurements, $15 \mathrm{~cm}$ height and $1.5-2.0 \mathrm{~m}$ wide rye stripes provided protection against a $9.7 \mathrm{~m} / \mathrm{s}$ wind event so no soil entrainment was observable at a 3-4 $\mathrm{m}$ distance from the last rye stripe. When the height of rye stripes was $120 \mathrm{~cm}$, the protected area reached a $25-30 \mathrm{~m}$ width zone.

From the 1980s wind erosion protection experiments were extended to the measurements conducted not only on sandy soils, but also on the heavy textured soils of Alföld.

The protection effects of different amount of irrigation, vegetation and crust forming materials decreasing the effects of wind erosion were also studied (LókI, J. 1994, 2003; LóкI, J. and SzAвó, J. 1997). Attention has been paid on the elaboration of environmentally sound technologies offering sufficient protection against wind erosion (LókI, J. 2004).

Vegetation reduces wind velocity at the soil surface and also decreases soil erodibility. The effect of vegetation on wind erosion was studied in wind tunnel with the help of wheat, and corn (LóкI, J. 2004). The wheat was sowed into rectangular sample holding trays in a way that the rows were $10 \mathrm{~cm}$ away from each oth- er along the length of the tray. Following the sowing, the plants developed to a height of $10-15 \mathrm{~cm}$ in $2-3$ weeks. Wind-blown sand, humic sand and Chernozem soils were used in the experiments. The experiments were conducted at different wind velocities $(7.2 \mathrm{~m} / \mathrm{s}$, $9.2 \mathrm{~m} / \mathrm{s}, 9.4 \mathrm{~m} / \mathrm{s}$ and $15 \mathrm{~m} / \mathrm{s}$ ) in two ways: the rows of plants were either perpendicular to or parallel to wind direction. In the case of the experiments with corn, stem distance between the plants was $12-15 \mathrm{~cm}$ and the distance between the rows was $38-42 \mathrm{~cm}$. Wind velocity measured at $10 \mathrm{~cm}$ height in front of the rows was always higher because the effect of the vegetation could not be felt yet. The velocity values measured between the second and third wheat rows which ran perpendicularly to wind direction were always considerably lower. The values measured behind the third row were especially impressive since they did not even reach the critical threshold velocity. A smaller scale of decrease may be experienced when increasing the wind velocity to a higher velocity value. This can be explained by the fact that the strong winds have beaten the weak plants and thus the height of the wheat rows flattened by the wind did not exceed $5 \mathrm{~cm}$. In the heights of $20-30 \mathrm{~cm}$ above the surface the wind could flow freely and therefore no considerable decrease could be detected in wind speed values.

When placing the rows of wheat parallel with the wind direction the movement of the air was less impeded by vegetation and thus wind velocity values did not decrease significantly between the rows between the front and the end of the sample-holding tray. In the case of the experiments with corn wind velocity did not decrease to that extent between and behind the corn rows as it did in the case of the wheat. This can be explained by the fact that the stalks of the densely sown wheat provided greater resistance against the air than the sparsely sown corn-stalks. The "flapping" movement of the corn-blades at some places resulted in whirling air flow. When studying the protective effect of the vegetation, the erodibility of the soils covered and not covered by vegetation was also measured. 
In the case of wheat erosion was much more intensive at the two edges of the tunnel where the surface was not covered by vegetation than it was in the protected zone. The weakened wind mainly transported finer granules between the rows of plants therefore the surface in front of the sample-holding tray was covered by rough sand by the end of the experiment. A considerable part of the eroded material moved ahead with a saltating movement close to the surface. The sediment amount at the heights of $10-40 \mathrm{~cm}$ never reached 10 per cent of the eroded soil (LóKI, J. and Négyesi, G. 2004) and was always less when trays were placed perpendicular to wind direction. The corn decreased the amount of erodible material to almost zero.

It was verified by the field and wind tunnel measurements that with the application of some chemical bonding agents (treace) on sandy soils a non-erodible crust will be formed on the soil surface providing proper wind erosion control. Because of their high cost and detrimental effect on the environment, the use of sand-fixing chemicals has been limited to small areas (LóKI, J. 1994). It was demonstrated that watering (irrigation) may offer a quick and effective protection against wind erosion. Watering with an amount equal to $5 \mathrm{~mm}$ rainfall efficiently reduced the erosive effect of even a strong $(15.5 \mathrm{~m} / \mathrm{s})$ wind for $4-6$ hours, depending on the soil texture. In areas covered by shifting sand wind erosion may quickly begin in stronger $(10-11 \mathrm{~m} / \mathrm{s})$ winds, even in the case of intensive, high volume and frequent irrigation because after the quick infiltration of water to the top layer it becomes dry very rapidly, even if the lower layers still remain wet (LókI, J. and NÉGYesI, G. 2003; NÉGYESI, G. 2007, 2008).

In the last years a remarkable attention was paid to studying the protection effects of shelterbelts in Nyírség (see Figure 1). A digital database of windbreaks was created on the basis of topographical maps and ortophotos. The effects of vegetation on wind velocity were measured with anemometers installed on the two sides of shelterbelts. The typifying of shelterbelts was prepared on the basis of main properties of shelterbelts (number of rows, porosity, orientation, functional type) and the measured data (LókI, J. and NÉGYesi, G. 2006, 2009). The results pointed to the fact that there are big differencies between the forest cover and the length of shelterbelt systems as well as in the tendency of changes in different parts of the Nyírség. On the one hand all the forests and shelterbelts are situated on the two sides of the Nyírség watershed: the dominance of shelterbelts on the northern side and forests on the southern side is in relation with soil properties. Nevertheless, the increase of forest area is continuous but the length of shelterbelts has decreased since the change of regime. In connection with wind shelterbelts we concluded that one third of the shelterbelts is planted improperly in the two study areas (Western and Southern Nyírség). It can be explained by the high rate of one-row shelterbelts, the discontinuity of shelterbelts and the improper direction of planting (NÉGYesI, G. 2009).

Nowadays GIS applications play an important role in the study of shelterbelts as wind erosion control measures. BARTUS, M. et al. (2017) proved by using the WEPS windbreak subroutine and the TEAM length factor function that shelterbelts were able to decrease the erosive capacity of the wind and in the case of winds blowing at $15 \mathrm{~m} / \mathrm{s}$ velocity it turned out that the most efficient protecting function is planting shelterbelts perpendicularly to prevailing winds.

\section{Spatial extent of wind erosion}

In Hungary wind erosion intensity depends on the conditions of climate, geomorphology, soil, vegetation and land use. Various attempts have been made to classify areas of wind erosion into categories based on the upper criteria.

According to the "Map of potential wind erosion of Hungary" by LóкI, J. (2003), 26.5 per cent of agricultural land in Hungary is strongly affected by wind erosion, where the 
critical threshold velocity of erosive winds is lower than $8.5 \mathrm{~m} / \mathrm{s}$ (Figure 2). However, this map is based only on a simplified soil texture classification and critical threshold velocity, whereas other factors (wind velocity, land use, climate) were not taken into account. Altough this map does not provide a full picture of the hazard but established a standard for classification of wind erosion, in which the magnitude of wind erosion was divided into five categories: no erosion, slight, moderate, high, very high erosion. Another important novelty of this map is that it was created on the basis of wind tunnel measurements. Erodibility categories were set based on the data measured in wind tunnel in an empirical way and these were associated with soil texture classes (Table 1).

Wind erosion is not only a landscape forming process but also a kind of natural hazard. SzAвó, J. et al. (2007) created a four-scale category system to evaluate wind erosion hazard in Hungary and they concluded that about 18 per cent of the country is strongly endangered by this process.

Mezósi, G. et al. (2015) integrated climate, vegetation and soil erodibility factors with fuzzy logic to create a wind erosion map of Hungary based on soil texture, climatological and land use data, and they verified their results by field investigations. Their verification included three test sites and did not contain comprehensive wind erodibility measurements. They took into consideration wind velocity above $9 \mathrm{~m} / \mathrm{s}$ to represent erosive wind; however, this value differs in the case of different soils.

PÁszTor, L. et al. (2016) provide a nationwide, spatially detailed assessment of the susceptibility of the land of Hungary to wind erosion integrating actual and representative wind tunnel measurements, the latest products provided by both digital soil mapping and digital climate characteristics mapping, furthermore the most recent land cover map provided by remote sensing. Threshold wind

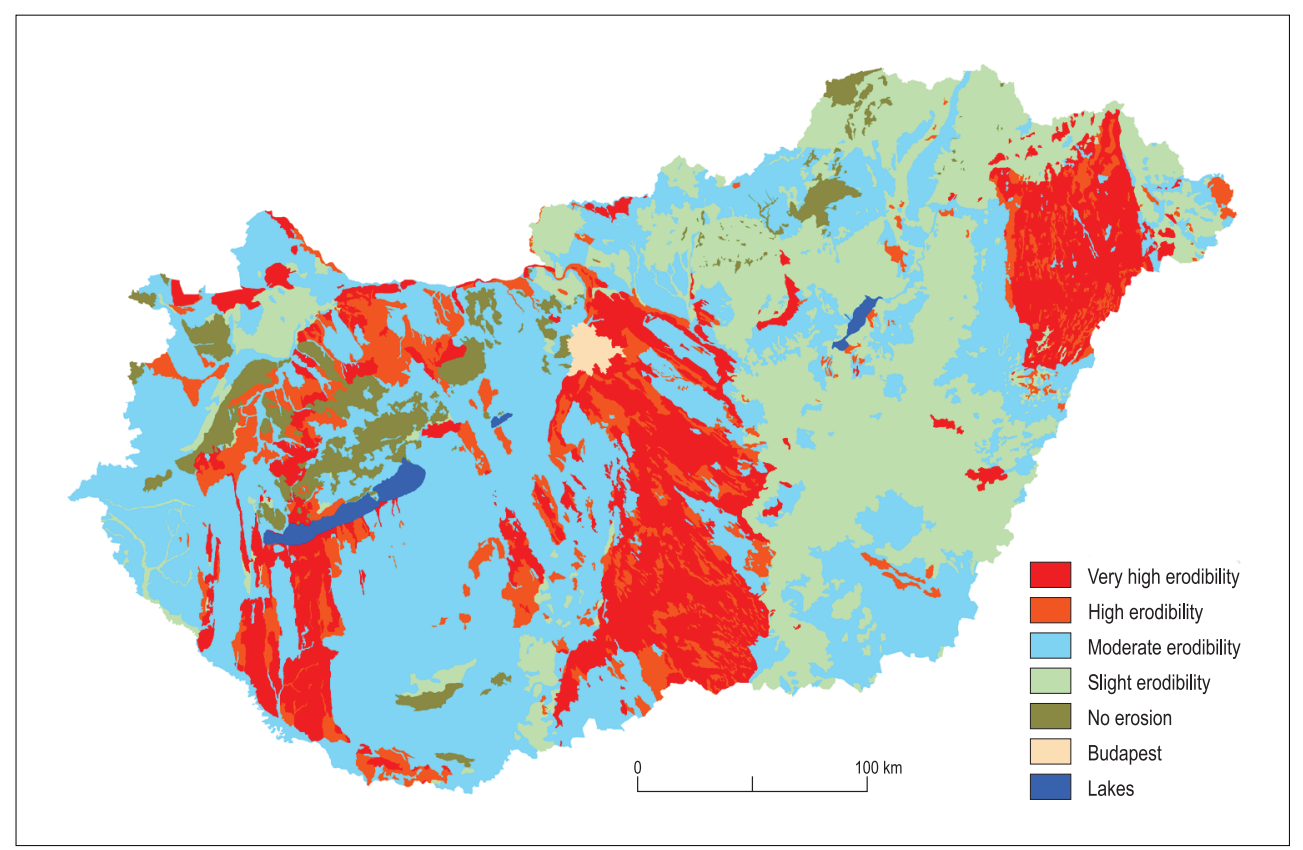

Fig. 2. Map of potential wind erosion of Hungary. Source: LóKI, J. (2003). 
Table 1. The main properties of erodibility categories*

\begin{tabular}{l|c|c|l}
\hline \multicolumn{1}{c|}{$\begin{array}{c}\text { Erodibility } \\
\text { categories }\end{array}$} & $\begin{array}{c}\text { Critical threshold } \\
\text { velocity, m/s }\end{array}$ & $\begin{array}{c}\text { Amount of eroded } \\
\text { material, g/5 minutes }\end{array}$ & \multicolumn{1}{|c}{$\begin{array}{c}\text { Soil texture } \\
\text { types }\end{array}$} \\
\hline Slightly sensitive & $>12.0$ & $<500$ & clay loam, clay \\
Less sensitive & $10.0-12.0$ & $500-1,000$ & silt loam \\
Moderately sensitive & $8.0-10.0$ & $1,000-1,500$ & loam \\
Sensitive & $6.5-8.0$ & $1,500-3,000$ & sandy loam \\
Highly sensitive & $<6.5$ & $>3,000$ & sand, loamy sand \\
\hline
\end{tabular}

*After LóKI, J. (2003).

velocity data were evaluated according to the texture classification of the samples (Table 2), the results were applied in the parametrization of the countrywide soil texture map compiled for the uppermost $(0-5 \mathrm{~cm})$ soil layer. Wind speed data were provided and processed by the Hungarian Meteorological Service. The aim was to determine how frequently wind speed exceeds a certain critical speed value at each grid point of a dense, $0.5^{\prime}$ spatial resolution grid.The outcome of wind speed exceedance calculations was the probability value of wind velocity exceeding critical values on hourly level.

The final map (Figure 3) was produced by masking out areas, which cannot be exposed to wind erosion due to their land use/land cover characteristics. According to the compiled map roughly 10 per cent of the country is affected by high risk of wind erosion. This is the consequence of the vegetation cover mainly and the occurrence of erosive winds, i.e. wind with velocity exceeding the local critical threshold value is only the second main factor. In the major part of the country the winds do not exceed the critical veloc- ity during the year, so even if soil and land use/land cover conditions promoted wind erosion, wind erosion damages would occur very rarely. It can be expected only in the case of strong cold fronts. In general, arable lands situated on lowlands and covered by sandy soils are the most endangered by wind erosion because they are featured by relatively small critical threshold velocity values (6-7 $\mathrm{m} / \mathrm{s}$ ), consequently, the winds having even gentle energy are capable to transport the upper soil layer.

Comparing the results of wind sensitivity mapping cunducted in Hungary to those of other authors (FunK, R. and Reuter, H.I. 2006; Borreli, P. et al. 2014), we could conclude that the regional distribution of areas that feature a higher risk of wind erosion is in good agreement with our results. Table 1 compares the extent of wind erosion susceptible areas in Hungary according to our classification with that of BorRelLI, P. et al. (2014).

In spite of the methodological differences, the figures are quite similar. SzAвó, L. et al. (1994) evaluated the extent of wind erosion based on the costs payed by insurance com-

Table 2. The extent of wind-susceptible areas in Hungary

\begin{tabular}{l|c|r|r|r}
\hline \multirow{2}{*}{ Erodibility categories } & \multicolumn{2}{|c|}{ Spatial distribution* } & \multicolumn{2}{c}{ Spatial distribution** } \\
\cline { 2 - 4 } & $\mathrm{km}^{2}$ & $\%$ & $\mathrm{~km}^{2}$ & 44.8 \\
\hline Non-erodible & $29,052.0$ & 31.2 & $41,707.5$ & 49.8 \\
Slight erodibility & $54,436.0$ & 58.5 & $46,375.0$ & 4.7 \\
Moderate erodibility & $5,208.0$ & 5.6 & $4,384.6$ & 0.6 \\
High erodibility & $4,333.0$ & 4.7 & 562.9 & 100.0 \\
Total & $93,030.0$ & 100.0 & $93,030.0$ & $\%$ \\
\hline
\end{tabular}

* Based on Pásztor, L. et al. (2016). **Based on Borelli, P. et al. (2014). 


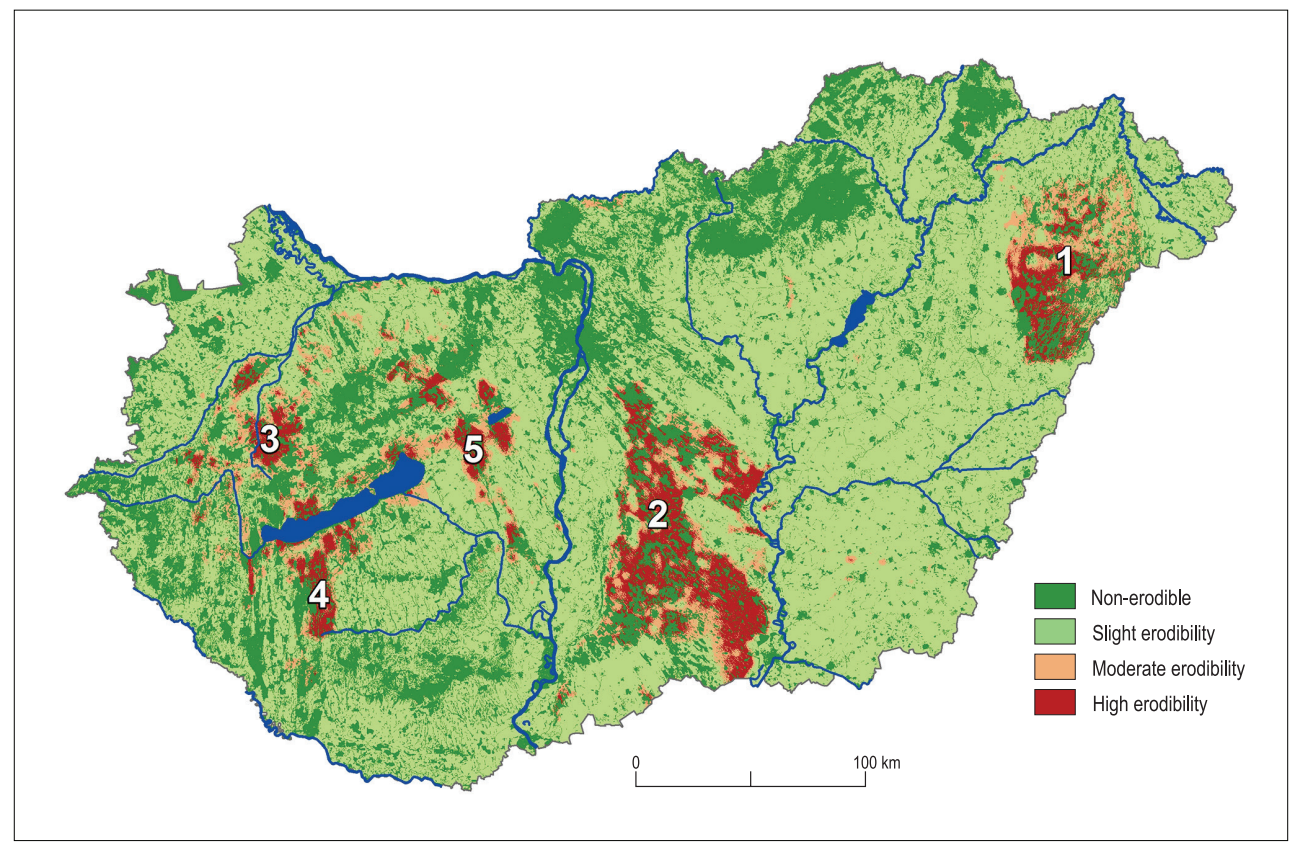

Fig. 3. Categorized wind erosion susceptibility map of Hungarian soils. The five distinct areas with typically higher wind erosion risk are numbered: Nyírség (1), Danube-Tisza Interfluve (2), Glacis in the foreground of the Transdanubian Mountains (3), Inner-Somogy (4), Transdanubian loess region (5). Source: PÁsztor, L. et al. (2016).

panies for wind erosion harms and their results coincide very well with our findings. Mezósı, G. et al. (2015) also got similar results based on less detailed input data. The main pattern of former approaches is reflected with reliable accuracy, nevertheless the recent map can be considered as a specific zooming into the spatial behaviour of wind erosion due to the application of significantly more detailed input data.

It is important to emphasise that the derived wind erosion map displays the current actual static state. The factors causing and affecting wind erosion (land cover and/ or land use, soil moisture content, management technology) vary both spatially and temporally. Aside from soil moisture content, the applied management technology plays an important role since the structure of soils even with identical texture categories may be differently damaged due to improper management techniques. Information on this factor could be collected by field observations and/or by large scale mapping. However, detailed and timely data, which could be used for nationwide mapping, are not currently available and cannot even be expected in the near future. A suitable solution could be the proper implication of these factors into process models and scenario-based runs of the developed models. The compiled maps in the present form provide a solid basis for the regional characterisation of wind erosion risk. They can be used for rational planning of protection concerning both soil conservation and environmental risk management.

We see some further possibilities for the improvement of the presented approach. It would be a major step forward to functionally relate the resistance of soils to wind ero- 
sion with their erodibility factor (EF), which can be calculated from basic soil properties (sand, silt, clay, organic matter and carbonate content), instead of texture classes. In this case critical threshold values could be estimated directly by EF and also indirectly by widely used soil data. Since nationwide soil property maps of these parameters have been very recently compiled, they could support a new approximation for mapping wind erosion susceptibility at national level. Eliminating the application of average values for each class, the expected accuracy of both thematic and spatial prediction is suggested to be improved.

\section{Wind erosion estimation models}

In order to obtain an accurate wind erosion rate and to evaluate different control measures, scientists from many countries have developed various kinds of wind erosion models. Fundamental models used today include the Wind Erosion Equation (WEQ) (Woodruff, N.P. and Siddoway, F.H. 1965), Simulation Model of Daily Wind Erosion Loss (Cole, G.W. et al. 1983), the Wind Erosion Prediction System (WEPS) (Hagen, L.J. 1991), the Revised Wind Erosion Equation (RWEQ) (FrYREAR, D.W. et al. 2000), and the Texas Erosion Analysis Model (TEAM) (Gregory, J.M. et al. 2004).

There has been relatively little research conducted on wind erosion models in Hungary, and at present no comprehensive model exists that could be used across Hungary to estimate wind erosion. At a small sample site, only the RWEQ and WEPS were tested. Mezôsi, G. and Szatmári, J. (1998) elaborated a wind erosion model of the Danube-Tisza Interfluve to delineate the areas endangered by wind erosion and to define the size of these areas and the mass of sandy soils removed by the wind in a short time. As Szatmári, J. (2006) stated, the main problem with the application of these models in Hungary is that it needs a meteorological data base which is diffucult to obtain and no long-term verification statements could be made regarding the model as we have only dealt with data for a single event and a single area so far. WEPS could deal with the detailed estimations in two dimensions. For a certain plot it proved to be a more reliable, controllable and suitable device than RWEQ. In our opinion, may be these models should be adopted carefully for Hungary because these are prepared on the basis of plot size measurements.

\section{Future possibilities in wind erosion research and control}

According to regional climate models of global climate change, the climate of Hungary is also becoming warmer and drier. In the next 50 years, the average annual temperature will increase by $1.0-1.9 \mathrm{C}^{\circ}$, while precipitation will decrease (BARTHOLY, J. et al. 2011), resulting in a reduction of soil moisture during the winter and spring. The increased intensity of human activities in association with climate change, has caused the expansion of wind affected land (Mezôsi, G. et al. 2016). For these reasons wind erosion control will continue to be a large problem for Hungary in the next century. In the future, a national strategy of wind erosion control must be put in place using prevention as the dominant factor. Areas with good water and soil conditions, where sustainable production can be maintained, must be identified and managed to maintain production with sufficient protection against wind erosion.

A key question in the study of wind erosion is quantitative assessment. Accurate wind erosion estimates and their regional distributions constitute critical information necessary for prevention and control, and they are important for related fields of study such as aeolian geomorphology, loess deposition and land degradation. The main scientific problems include: (1) a need for precise and standardized methods for 
measuring wind erosion; (2) comprehensive, reliable data on wind erosion for the whole country; and (3) a wind erosion prediction model or models applicable to the whole area of Hungary.

Hungary should also recognize that changes in land management practices are necessary to decrease the rate of wind erosion. There are two aspects of land management practice that Hungary is following, or needs to follow to control wind erosion. First, the applied land use practices should be adjusted and optimized. Secondly, improve the application of farmland, land management practices to reduce wind erosion including strip cropping, rotations, crop residue management, deep and zero tillage.

\section{Conclusions}

Hungarian wind erosion research has made a considerable progress, including the compilation of a wind erosion map of Hungary; developments in measurement techniques and the application of adequate methods of wind erosion control. Nevertheless, the potential problems of wind erosion in the future remain enormous.

The future of wind erosion control in Hungary must concentrate on the strategy of using prevention as the dominant measure combined with land management and engineering control practices involving the adjustment of land use patterns. Hungary should also increase international cooperation on wind erosion research and control. Furthermore, Hungary has a relatively large agricultural area where wind erosion processes interact with water erosion, displaying a complexity of fluvio-aeolian processes. It is important that wind erosion research should be extended in order to solve wind erosion problems of Hungary.

Acknowledgement: The research was supported by National Research, Development and Innovation Office - NKFIH KH 126725 and 108755.

\section{REFERENCES}

Anderson, R.S. and Haff, P.K. 1988. Simulation of eolian saltation. Science 241. (4867): 820-823.

Armbust, D.V. and Bilbro, J.D. 1997. Relating plant canopy characteristics to soil transport capacity by wind. Agronomy Journal 89. 157-162.

Baddock, M.C., Zobeck, T.M., Scott VAn Pelt, R. and FREDRICKSON, E.L. 2011. Dust emissions from undisturbed and disturbed, crusted playa surfaces: cattle trampling effects. Aeolian Research 3. (1): 31-41.

Bartholy, J., Haszpra, L. and Bozó, L. 2011. Climate change - 2011. Climate scenarios for the Carpathian Basin. Budapest, MTA-ELTE.

Bartus, M., Barta, K., Szatmári, J. and Farsang, A. 2017. Modeling wind erosion hazard control efficiency with an emphasis on shelterbelt system and plot size planning. Zeitschrift für Geomorphologie 61. 123-133.

Bat, R.G. and Peabody, S.A. 1999. Threshold friction velocities for large pebble gravel beds. Journal of Geophysical Researches 104. (24): 273-279.

Belnap, J. and Gillette, D.A. 1997. Disturbance of biological soil crusts: impacts on potential wind erodibility of sand desert soils in Southeastern Utah. Land Degradation and Development 8. (4): 355-362.

Bisal, F. and Hsieh, J. 1966. Influence of moisture on erodibility of soil by wind. Soil Science 102. (3): 143-146.

Blaskó, L., KaruczKa, A., Nyíri, L. and Zsembeli, J. 1995. Wind erosion sensitivity analysis of cohesive soils. Agrokémia és Talajtan 44. (3-4): 497-503.

Bodolay, I. 1965a. Protection from wind erosion on irrigated sand areas. Agrokémia és Talajtan 14. (1-2): 1-15.

Bodolay, I. 1965b. Process and dynamics of wind erosion. Agrokémia és Talajtan 14. 183-198.

BoDolay, I. 1966a. The role of soil tillage in wind erosion. Agrokémia és Talajtan 15. 153-166.

Bodolay, I. 1966b. Altering physical features affecting wind erosion. Agrokémia és Talajtan 16. 372-383.

Bodolay, I. and PuszTai, A. 1968. Successfull protection against wind erosion with gramoxon covering. Magyar Mezógazdaság 23. 15. (in Hungarian)

Bodolay, I., Kazó, B. and Máté, F. 1971. Application of soil-fixing latex emulsion. Meliorációs Információk és Közlemények I. Budapest, MÉM. (in Hungarian)

Borrelli, P., Ballabio, C., Panagos, P. and Montanarella, L. 2014. Wind erosion susceptibility of european soils. Geoderma 232. 471-478.

Borsy, Z. 1972. Examination of wind erosion on sandy areas in Hungary. Földrajzi Közlemények 96. 156-160.

Borsy, Z. 1974. The principles of sand movement and the protection against wind erosion. Academical Doctoral Thesis, Debrecen, Kossuth Lajos University. Manuscript. (in Hungarian)

Buró, B. 2016. Examination of recens an subrecens landforming processes on sample site sin Nyírség. 
Doctoral Thesis. Debrece, Debreceni Egyetem. Manuscript. (in Hungarian)

Buró, B., Tóth, Cs., LóKI, J., Andrási, B. and Négyesi, G. 2018. Field wind erosion measurement on a hummocky dune in Nyírség. In Kárpát-medencei Környezettudományi Konferencia XIV. Ed.: FüLEKY, Gy., 47-51. (in Hungarian)

Chen, W., Zhibao, D., Li, Z. and YANG, Z. 1996. Wind tunnel test of the influence of moisture on the erodibility of loessial sandy loam soils by wind. Journal of Arid Environments 34. (4): 391-402.

ChepIL, W.S. 1942. Measurements of wind erosiveness of soils by dry sieving procedures. Scientific Agriculture 23. (3): 154-160.

ChepIL, W.S. 1954. Factors that influence clod structure and erodibility of soil by wind: III. Calcium carbonate and decomposed organic matter. Soil Science 77. (6): 473-480.

CHEPIL, W.S. 1956. Influence of moisture on erodibility of soil by wind. Soil Science Society Proceedings 20. (2): 288-291.

ChepIL, W.S. 1958. Soil conditions that influence wind erosion. Technical Bulletin No. 1185. Washington DC, USDA Agricultural Research Service.

Cole, G.W., Lyles, L. and Hagen, L.J. 1983. A simulation model of daily wind erosion loss. Transactions of the American Society of Agricultural Engineers 26. (6): 1758-1765.

De Rouw, A. and Rajot, J.L. 2004. Soil organic matter, surface crusting and erosion in Sahelian farming systems based on manuring or fallowing. Agriculture Ecosystems and Environment 104. (2): 263-276.

Egerszegi, S. 1961. About the importance of sand protecting. Magyar Mezógazdaság 16. 6. (in Hungarian)

EGERSZEGI, S. 1962. Main aspects of theory and application of the substantive fixing of sandy soils. Budapest, MTA Agrártudományok Osztályának Közleményei 21. 1-2. (in Hungarian)

FArsang, A., Szatmári, J., NéGyesi, G., Bartus, M. and BARTA, K. 2011. Estimation of nutrient movement caused by wind erosion on chernozem soils in wind tunnel experiments. Agrokémia és Talajtan 60. (1): 87-102. (in Hungarian)

Farsang, A., Bartus, M., Barta, K. and Szatmári, J. 2013a. In situ determination of chernozems with portable wind tunnel. Talajvédelem 21. (1-2): 157-169.

Farsang, A., Bartus, M., Szatmári, J., Barta, K. and Duttmann, R. 2013b. In situ determination of the wind erosion caused nutrient loss on Chernozems by portable wind cannel experiments. Journal of Earth Science and Climatic Change 4. Special Issue.

Farsang, A., Bartus, M., Barta, K. and Szatmári, J. 2017. Connection between wind erosion vulnerability and soil properties of aggregated soils: results of portable wind tunnel experiments on chernozems of the southern. parts of the Great Hungarian Plain. Földrajzi Közlemények 141. (1): 1-14. (in Hungarian)

Fryrear, D.W., Bilbro, J.D., Saleh, A., Schomberg, H., Stout, J.E. and Zовеск, T.M. 2000. RWEQ: Improved wind erosion technology. Journal of Soil and Water Conservation 55. 183-189.

Fryrear, D.W., Saleh, A., Bilbro, J.D., Zobeck, T.M. and Stout, J.E. 1996. Field tested wind erosion model. In Proceedings of the International Symposium 'Wind erosion in West Africa: the problem and its control'. Eds.: Buerkert, B., Allison, B.E. and von Oppen, M., Weikersheim, Margraf Verlag, 343-355.

FunK, R. and Reuter, H.I. 2006. Wind erosion. In Soil erosion in Europe. Eds.: Boardman, J. and Poesen, J., Chichester, John Wiley, 563-582.

Funk, R., Deumlich, D., Voelker, L. and Steidl, J. 2004. GIS application to estimate the wind erosion risk in the Federal State of Brandenburg. In Wind Erosion and Dust Dynamics. Eds.: Goossens, D. and RIKsEn, M., Wageningen, ESW Publications, 139-150.

GÁL, J. 1966. Prevention of wind erosion with windbreaks. Agrokémia és Talajtan 15. (2): 199-211. (in Hungarian)

GÁL, J. 1974. Protection against wind erosion and air pollution with shelterbelts. Az Erdö 23. (7): 321-326. (in Hungarian)

Goossens, D. 2004. Effect of soil crusting on the emission and transport of wind-eroded sediment: field measurements on loamy sandy soil. Geomorphology 58. (1-4): 145-160.

Gregory, J.M., Wilson, G.R., Singh, U.B. and DARWISH, M. 2004. TEAM: Integrated, processbased wind-erosion model. Environmental Modelling and Software 19. (2): 205-215.

Hagen, L.J. 1991. A wind erosion prediction system to meet user needs. Journal of Soil and Water Conservation 46. (2): 106-111.

Hevia, G.G., Buschiazzo, D.E., Heprer, E.N., Urioste, A.M. and Anton, E.L. 2003. Organic matter in size fractions of soils of the semiarid Argentina. Effects of climate, soil texture and management. Geoderma 116. (3-4): 265-277.

Hevia, G.G., Mendez, M. and Buschiazzo, D.E. 2007. Tillage affects soil aggregation parameters linked with wind erosion. Geoderma 140. (1-2): 90-96.

KARÁCsONY, J. 1974. Instrumental analyses of surface winds. Official Issue of Hungarian Meteorological Service 13. Budapest, OMSZ, 163-167. (in Hungarian)

Keller, B., Szabó, J., Centeri, Cs., Jakab, G. and Szalai, Z. 2018. Different land-use intensities and their susceptibility to soil erosion. Agrokémia és Talajtan 67. (1-2): 1-10.

Király, M. and Karácsony, J. 1977. Climatological factors triggering wind erosion and experiments to measure amount of eroded material. Official Issue of 
Hungarian Meteorological Service 44. Budapest, OMSZ, 205-210. (in Hungarian)

LanCAster, N. 1995. Geomorphology of desert dunes. London, Routledge.

Leuven, M.L. 1982. Influence of roughness elements and soil moisture on the resistance of sand to wind erosion. In Aridic Soils and Geomorphic Processes. Ed.: YaAlon, D.H., Braunschweig, Catena Verlag. 161-173.

Livingstone, I. and Warren, A. 1996. Aeolian geomorphology: An introduction. Harlow, Longman.

LóKI, J. 1994. Physical geographical examinations in the north part of Danube-Tisza Interfluve from the aspect of agriculture. Kandidátusi értekezés, Debrecen. Manuscript. (in Hungarian)

LókI, J. 2000. The study of wind erosion on different soil by wind tunnel. Anthropogenic Aspects of Landscape Transformations 1. 37-44.

LóKI, J. 2003. Mechanism of wind erosion and its effect in Hungary. Academical Doctoral Thesis, Debrecen. Manuscript. (in Hungarian)

LóKI, J. 2004. Possibilities of protection against wind erosion. Földtudományi tanulmányok 1 . Tiszteletkötet Dr. Justyák János 75. születésnapjára. Ed.: TAR, K., Debrecen, Debreceni Egyetem, 105-115.

LóKI, J. 2008. Study of eolian processes in Hungary. Földrajzi tanulmányok 2. Ed.: SzABó, J., Debrecen, Debreceni Egyetem, 173-183.

LóKI, J. and NÉGYesI, G. 2003. Effect of soil crust on wind erosion. Acta Geographica Geologica et Meteorologica Debrecina 36. 55-64.

LóKI, J. and NÉGYESI, G. 2004. Wind Erosion protection effect of the vegetation - based on wind-tunnel experiments. Anthropogenic Aspects of Landscape Transformations 3. 61-69.

LóKI, J. and NÉGYESI, G. 2006. Wind erosion protection effect of shelterbelts in Hungary. In Morphological and sedimentological effects of eolian activity. Ed.: Nowaczyк, B., Poznań, Association of Polish Geomorphologist, 40-48.

LóKI, J. and Szabó, J. 1997. Neuere Windkanaluntersuchungen der Deflationssensibilitat von Böden des Ungarischen Tieflandes. Zeitschrift für Geomorphologie 111. 145-159.

Lóki, J., Rajkai, K., Czyz, E.A., Dexter, A.R., DiazPereira, E., Dumitriu, E., Enache, R., Fleige, H., Hom, R., De la Rosa, D. and Simota, C. 2005. Wind erodibility of cultivated soils in North-east Hungary. Soil and Tillage Research 82. 39-16.

Lopez, M.V., Gracia, R. and Arrue, J.L. 2000. Effect of reduced tillage on soil surface properties affecting wind erosion in semiarid fallow lands of Central Aragon. European Journal of Agronomy 12. (3-4): 191-199.

Mezósi, G. and Szatmári, J. 1998. Assessment of wind erosion risk on the agricultural area of the southern part of Hungary. Journal of Hazardous Materials 61. (1-3): 139-153.
Mezósi, G., Blanka, V., Bata, T., Kovács, F. and Meyer, B. 2015. Estimation of regional differences in wind erosion sensitivity in Hungary. Natural Hazards and Earth System Sciences Discussions 15. 97-107.

Mezősi, G., Blanka, V., Bata, T., Ladányi, Zs., KeménY, G. and Meyer, B.C. 2016. Assessment of future scenarios for wind erosion sensitivity changes based on ALADIN and REMO regional climate model simulation data. Open Geosciences 8. (1): 465-477.

Négyesi, G. 2007. Formation of soil crusts and measuring crust resistance by penetrometer. Acta Geographica Silesiana 1. 35-39.

NÉGYESI, G. 2008. Studying the wind erosion reducing effect of irrigation on soils of the Hajdúhát. In Anthropogenic aspects of landscape transformations 5. Eds.: LóKI, J. and Szabó, J., Debrecen, University of Debrecen, 71-79.

NÉGYESI, G. 2009. Typifying shelterbelts in Hungary. Acta Geographica Silesiana 5. 43-52.

NÉGYESI, G. 2018a. Application possibilities of erodibility factor (EF) in the case of soils in Nyírség. Agrokémia és Talajtan 67. (2): 199-212.

NÉGYesi, G. 2018b. Surveying the spatiotemporal changes of afforestation in the Nyírség - from the aspect of wind erosion. Tájökológiai Lapok 16. (2): 113-128. (in Hungarian)

NÉGyesi, G., LókI, J., Buró, B. and Szabó, Sz. 2016. Effect of soil parameters on the threshold wind velocity and maximum eroded mass in a dry environment. Arabian Journal of Geosciences 9. 588-599.

Nelson, R.G., Wagner, L.E. and K. Stueve, K. 1993. Mass reduction of standing and flat crop residues by selected tillage implements. In Proceedings of ASAE Winter Meeting. Chicago, IL 14-17. December 1993. Paper No. 932539.

NicKLING, W.G. 1978. Eolian sediment transport during dust storms: Slims River Valley. Yukon Territory. Canadian Journal of Earth Science 15. (7): 1069-1084.

PálfaI, I. 2011. Droughty years on the Great Hungarian Plain between 1931-2010. In Environmental Changes and the Great Hungarian Plain. Ed.: RakonczaI, J., Békéscsaba, MTA RKK ATI, 87-96.

Pásztor, L., Négyesi, G., Laborczi, A., Kovács, T., László, E. and BiHaRI, Z. 2016. Integrated spatial assessment of wind erosion risk in Hungary. Natural Hazards and Earth System Sciences 16. 2421-2432.

Rajot, J.L., Alfaro, S.C., Gomes, L. and Gaudichet, A. 2003. Soil crusting on sandy soils and its influence on wind erosion. Catena 53. (1): 1-16.

Saleh, A. and Fryrear, D.W. 1995. Threshold wind velocities of wet soils as affected by windblown sand. Soil Science 160. (4): 304-309.

ShaO, Y. 2008. Physics and modelling of wind erosion. $2^{\text {nd }}$ edition. Springer Verlag.

Shao, Y. and Lu, H. 2000. A simple expression for wind erosion threshold friction velocity. Journal of Geophysical Researches 105. (22): 437-443. 
Sharratt, B.S. and Vaddella, V. 2014.Threshold friction velocity of crusted windblown soils in the Columbia Plateau. Aeolian Research 15. 227-234.

Shi, P., Ping, Y. and Nearing, M.A. 2004. Wind erosion research in China: Past, present and future. Progress in Physical Geography 28. 366-386.

Skidmore, E.L. 1986. Soil erosion by wind: an overview. In Physics of desertification. Ed.: EL-BAz, F. and Hassan, M.H.A., Dordrecht, Martinus Nijhoff, 261-273.

Szaвó, J., Lóкi, J., Szaвó, G. and Tóтн, Cs. 2007. Natural hazards in Hungary. Földrajzi Értesítö / Hungarian Geographical Bulletin 56. (1-2): 15-37.

Szabó, L., Karácsony, J. and Székely, Zs. 1994. Wind erosion problems in Hungary. Agrochemistry and Soil Science 43. (1-2): 109-112.

SzATMÁRI, J. 2004. Szélerózió-veszélyeztetettség értékelése a Duna-Tisza közén RWEQ modell alkalmazásával (Evaluation of wind erosion hazards in the Danube-Tisza Interfluve applying RWEQ model). In Táj, Tér, Tervezés: Geográfus Doktoranduszok VIII. Országos Konferenciája tudományos közleményei, Ed.: Kovács, F., Szeged, SZTE, 100-110. (in Hungarian)

Szatmári, J. 2006. Application of GIS methods and process models in wind erosion researches. Doctoral Thesis. Szeged. Manuscript.

SzeIFrID, E. and KIs, L. 1969. Wind erosion measurements on sandy soils near Cegléd. In Az Agrártudományi Egyetem Közleményei 1969. Ed.: Bencze, J., Gödöllő, Agrátudományi Egyetem, 349-362. (in Hungarian)

TAтARKo, J. 2011. Long term monitoring of wind erosion induces changes to soil properties in Western Kansas. In International Symposium on Erosion and Landscape Evolution, 18-21. September 2011. Anchorage, Alaska. Eds.: Flanagan, D.C., Ascough, J.C. and Nieber, J.L., St. Joseph, ASABE, 18-21.

TAtÁrvÁri, K. and NÉGYeSI, G. 2013. Nutrition loesses of sandy soils on the basis of wind tunnel experiments. Agrokémia és Talajtan 62. (2): 285-298.

Troen, F.R., Hobbs, J.A. and Donahue, R.L. 1980. Soil and water conservation for productivity and environmental protection. Prentice-Hall, Englewood Cliffs.
Waltner, I., Pásztor, L., Centeri, Cs., Takács, K., Pirkó, B., Koós, S. and László, P. 2018. Evaluating the new soil erosion map of Hungary A semi-quantative approach. Land Degradation and Development 29. (49): 1295-1302.

Wang, T., David, A., Wedin, D.A., Franz, T.E. and Hiller, J. 2015. Effect of vegetation on the temporal stability of soil moisture in grass-stabilized semiarid sand dunes. Journal of Hidrology 521. 447-459.

Westsik, V. 1922. Features of loose sandy soils. Köztelek 32. 123-140. (in Hungarian)

Westsik, V. 1951. Causal tillage of loose sandy soils. Budapest, Mezőgazdasági Kiadó. (in Hungarian)

WoodrufF, N.P. and Siddoway, F.H. 1965. A wind erosion equation. Proceedings of the Soil Science Society of America 29. (5): 602-608.

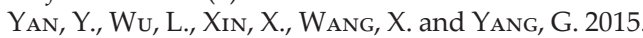
How rain-formed soil crust affects wind erosion in a semi-arid steppe in northern China. Geoderma 249-250. 79-86.

ZhaNG, Y.M., WANG, X.Q., WANG, W.K., YANG, W.K. and ZHANG, D.Y. 2006. The microstructure of microbiotic crust and its influence on wind erosion for a sandy soil surface in the Gurbantunggut Desert of Northwestern China. Geoderma 132. (3): 441-449.

Zовеск, T.M. 1991. Abrasion of crusted soils: influence of abrader flux and soil properties. Soil Science Society of America Journal 55. (4): 1091-1097.

Zobeck, T.M., Baddock, M., Van Pelt, R.S., TAtarko, J. and Acosta-Martinez, V. 2013. Soil property effects on wind erosion of organic soils. Aeolian Research 10. 43-51.

Zobeck, T.M., PARker, N.C., HASKell, S. and Gouding, K. 2000. Scaling up from field to region for wind erosion prediction using a field-scale wind erosion model and GIS. Agriculture, Ecosystem and Environment 82. 247-259. 